\title{
The Brotherhood, the City and the Land: Patriarchal Archives and Scales of Analysis of Greek Orthodox Jerusalem in the Late Ottoman and Mandate Periods
}

\author{
Angelos Dalachanis and Agamemnon Tselikas
}

Could opening the archives of the Greek Orthodox patriarchate endanger the peaceful coexistence of communities in Jerusalem? What would be the impact of these largely unexplored records on our understanding of the history and life of Jerusalem? These questions echo the apprehension, which prevails in some of Jerusalem's ecclesiastical and academic circles, both within and outside of the patriarchate. ${ }^{1}$ This apprehension is not without reason. The Greek Orthodox patriarchate is the oldest Christian institution in the Holy Land, the principal custodian of the Christian sacred shrines and one of the most important nonstate landowners in Palestine and Israel today. ${ }^{2}$ It is administered by the Brotherhood of the Holy Sepulchre. Because of the patriarchate's central and multilayered role, its archives, which cover a period of almost a thousand years, are expected to provide information and answers to inquiries regarding the city's Christian population and beyond. These archives record not only the patriarchate's institutional life and its relationship with imperial, religious, and state authorities throughout centuries, but also the life of the Greek Orthodox community, namely of the Greek and Palestinian Arab subcommunities that formed the clergy and the flock. Additionally, these records contribute to our understanding of ordinary Jerusalem life and of the meaning of citadinité in this setting. This chapter is the outcome of the collaboration between an archivist and a historian. We aim to present - for the first time in a language other than Greek - the collections and series of the patriarchate's archives, especially from the late Ottoman and British Mandate periods, and to

1 We are grateful to His Beatitude, the Patriarch of the Holy City of Jerusalem and all Palestine, Syria, Arabia, beyond the Jordan River, Cana of Galilee, and Holy Zion, Theofilos III, who permitted us to consult the records of the patriarchate.

2 Itamar Katz and Ruth Kark, "The Church and Landed Property: The Greek Orthodox Patriarchate of Jerusalem," Middle Eastern Studies 43, no. 3 (2007).

(C) ANGELOS DALACHANIS AND AGAMEMNON TSELIKAS, 2018 | DOI:10.1163/9789004375741_009 This is an open access chapter distributed under the terms of the prevailing CC-BY-NC-ND License at the time of publication. 
understand Jerusalem's citadinité through the comparison of the patriarchate's involvement in the city's affairs on broad and narrow scales. We argue that a deep knowledge of the institutional framework of the Greek Orthodox patriarchate is necessary in order to approach the archival fond itself. In particular, we argue that it is important to consider the material and intellectual organization, classification, and, finally, the history of the patriarchate.

\section{The Patriarchate: A Steadfast Player in an Ever-Changing Context}

The Greek (or Rum) Orthodox patriarchate in Jerusalem, which sees itself as the "mother of the churches," is an independent, self-governed church headed by the patriarch, who is considered to be the successor of St. James, the first bishop and patron saint of the Holy City. ${ }^{3}$ The terms Greek Orthodox and Rum Orthodox are in essence synonyms. The Ottoman Turkish term Rüm signifies the Byzantine roots of the institution when Constantinople was known as the "New Rome" and refers also to the millet-i Rüm, the Orthodox confessional community that was formed during the Tanzimat and administered itself under its own set of rules. To this day, some Palestinian Arab Greek Orthodox use the term Rüm to distinguish themselves from the term "Greek," which they object to because of the ethnic and national affiliation that it signifies.

The Greek Orthodox patriarchate is one of the four ancient Orthodox patriarchates. The other three are the Ecumenical Patriarchate of Constantinople;

3 For the history of the patriarchate until the first decades of the twentieth century, see Chrysostomos A. Papadopoulos, Istoria tis ekklisias ton Ierosolymon [History of the church of Jerusalem] (1910, repr., Thessaloniki: Pournaras, 2010); Konstantinos Papastathis, "To keno exousias sto Patriarcheio Ieorosolymon, 1917-1918" [The power vacuum within the Orthodox patriarchate of Jerusalem, 1917-1918], Historica 51 (2009); Papastathis, "Secularizing the Sacred: The Orthodox Church of Jerusalem as a Representative of Greek Nationalism in the Holy Land," Modern Greek Studies Yearbook 2014-15, 30-31 (2016); Daphne Tsimhoni, "The Greek Orthodox Patriarchate of Jerusalem during the Formative Years of the British Mandate in Palestine," Asian and African Studies 12, no. 1 (1978). For a broader but still Greek-centric perspective, see Sotirios Roussos, "Greece and the Arab Middle East: The Greek Orthodox Communities in Egypt, Palestine and Syria, 1919-1940" (PhD diss., soAs, University of London, 1994). The most detailed study on the matter remains the report of the Bertram and Young Commission: Anton Bertram and John W. A. Young, The Orthodox Patriarchate of Jerusalem: Report of the Commission Appointed by the Government of Palestine to Inquire and Report upon Certain Controversies between the Orthodox Patriarchate of Jerusalem and the Arab Orthodox Community (London: Oxford University Press, 1926). 
the Patriarchate of Antioch and all the East, now based in Damascus; and the Patriarchate of Alexandria and All Africa. The cities hosting the four patriarchal sees may appear odd to a contemporary observer who is not familiar with the history of Christianity in the area, yet they correspond to the centers of the initial expansion of Eastern Christianity in a direction opposite to Rome: namely southwards and eastwards of Constantinople. Unlike in the Catholic Church, there is no supreme governing authority among the four patriarchates. Rather there is an honorary hierarchy within which the Jerusalem institution is ranked fourth (after Constantinople, Alexandria and Antioch) because it was the last of the four to be created after the Council of Chalcedon in 451. From this point on, the Jerusalem bishopric was upgraded to a patriarchate, mostly for symbolic reasons and despite its restrained territory. The patriarchate initially comprised of only Jerusalem and its close environs. ${ }^{4}$

The jurisdiction of the patriarchate of Jerusalem now extends far beyond the Holy City. It stretches from the eastern coast of the Mediterranean to the Arabian Peninsula. Within this broad geographical area, where numerous states now exist, the political, demographic and religious map has been constantly changing over the last 1,566 years, often quite radically. After centuries as a Roman province, the area became part of Byzantium and later of the Arab caliphates. The Ayyubid and Mamluk dynasties, the Ottomans, and later the British came to rule over it, though one must take into account the Crusaders, the Mongols and the Seljuqs. In all cases the imperial and other administrative centers were located far away from Jerusalem, a fact that contributed to the patriarchate's autonomy as well as to the consolidation of its authority over the sacred shrines. Successive scissions in Eastern Christianity from the fourth century onwards split the Christians of the region into various doctrines and churches, with differences stemming from geographical position, language, and sets of symbolisms.

Despite the frequent changes in the region, the patriarchate managed to preserve the same solid yet atypical administrative model throughout the centuries: it has always been run by the Brotherhood of the Holy Sepulchre (Hagiotaphite). ${ }^{5}$ It is worth asking how and why this came about. After the new Christian religion became the official faith of the Roman state and monumental churches were built, a considerable number of clergymen who had

4 Louis Bréhier, Le monde byzantin, vol. 2, Les institutions de l'Empire byzantin (Paris: Mimésis, 2015), 363-65.

5 Memorandum on the Monastic Character of Administration of the Greek Orthodox Church if Jerusalem (Jerusalem: Greek Convent Press, 1923). 
been leading a monastic life created the regiment of spoudaioi (magnificent) in 326. The spoudaioi were lettered monks dedicated to study and devoted to the guardianship and maintenance of the Church of the Resurrection in Jerusalem. This regiment developed over time into the well-known brotherhood of today. Senior bishops were recruited or appointed from their ranks, a practice that continued even after the spoudaioi system became the brotherhood - most probably during the fifth century. ${ }^{6}$

During the Byzantine period, the Jerusalem Church was highly regarded by the Ecumenical Patriarchate of Constantinople. The fact that Jerusalem bishops were invited to the capital to participate in ecumenical synods is a strong indication of this relationship. After the Ottoman conquest of Palestine in $1516-17$, the links of the Jerusalem patriarchate with the Ecumenical Patriarchate became more pronounced and contributed to the Hellenization of the former. This occurred mainly because the selection of the new patriarch in Jerusalem was highly influenced by the Ecumenical Patriarchate, controlled by a Greek-speaking clergy, and the equally Greek-speaking Stambouliote elite of Fanariotes. After his election, the patriarch of Jerusalem resided in Istanbul, whereas the brotherhood supervised the Holy Land in situ. According to the regulations of the brotherhood, which were set in the seventeenth century, the patriarch had to be the head of the brotherhood and was chosen from among its members. ${ }^{7}$ Theoretically, membership in the brotherhood has always been free and independent of any ethnic or national affiliation. However, the choice of the bishops and the patriarch has been customarily made among the Greek-speaking members of the brotherhood and, after the foundation of the Greek state in 1830, among Greek nationals. Thus, the brotherhood's functioning, which resembles that of a "closed corporation," 8 explains how the patriarchate's Greek character has been preserved throughout the years despite pressure from several Slavic churches to gain control of the Christian sacred shrines or the patriarchate itself. As a result of its strong Greek character, all requests from Palestinian Arab Christians to participate more actively in the patriarchate's governance have been rejected. This is in spite of the fact that Palestinians have constituted a large - and often the

6 Panayiotis J. Vatikiotis, "The Greek Orthodox Patriarchate of Jerusalem: Between Hellenism and Arabism," Middle Eastern Studies 30, no. 4 (1994).

7 Sotirios Roussos, "Eastern Orthodox Perspectives on Church-State Relations and Religion and Politics in Modern Jerusalem," International Journal for the Study of the Christian Church 5 , no. 2 (2005).

8 Vatikiotis, "The Greek Orthodox Patriarchate." 
largest - part of the Greek Orthodox congregation. Today they make up the congregation almost exclusively. ${ }^{9}$

The close links between Jerusalem and the Ecumenical Patriarchate of Constantinople, and consequently the Ottoman administration, undoubtedly contributed to the rights and privileges that the Ottoman authorities granted to what was also referred to as the Church of Zion. Due to the strong identification of the patriarchate's senior clergy with the members of the brotherhood, the fraternity and the patriarchate have become almost inseparable entities and maintain the role of custodians of the holy sites, even until today, sometimes jointly with the Roman Catholic and the Oriental churches (Armenian, Coptic and Ethiopian) according to the Status Quo, the set of regulations established during the Ottoman era. ${ }^{10}$ During the nineteenth century, Greekspeaking and Greek-born individuals progressively felt they belonged to a distinct ethnicity. A similar sentiment can be found among many other confessional communities of the Ottoman Empire including Palestinian Arabs, who also gradually developed ethnic or national aspirations. The foundation of the Greek state in 1830 and the impact it had across the eastern Mediterranean consolidated this feeling and the dominant place of the Greek clergy within the patriarchate. Likewise, the patriarchate was placed, to an extent, under the protection of the newborn state and remains so to this day. The Greek clergy still controls this institution, as well as the other two ancient patriarchates in Constantinople and in Alexandria. However, this is no longer the case for the patriarchate of Antioch, whose Arab-speaking priesthood took control after the native Arab Greek Orthodox, Meletios of Latakia, was elected patriarch in 1899, taking advantage of the emerging wave of Arab nationalism in the region. ${ }^{11}$

9 For the issue of the Palestinian Arabs in Jerusalem and Palestine during the Mandate, see Laura Robson, Colonialism and Christianity in Mandate Palestine (Austin: University Press of Texas, 2011); Noah Haiduc-Dale, Arab Christians in British Mandate Palestine: Communalism and Nationalism, 1917-1948 (Edinburgh, Edinburgh University Press, 2013).

10 Konstantinos Papastathis, "To proskynimatiko zitima stin Palestini: Apo tin othomaniki kyriarchia stin vretaniki entoli 1914-1931" [The question of the Holy Places of Palestine: From Ottoman rule to the British Mandate, 1914-1931] (PhD diss., Aristotle University of Thessaloniki, 2008); Papastathis, "Religious Politics and Sacred Space: The Orthodox Strategy on the Status Quo Question, 1917-1922," Journal of Eastern Christian Studies 65, nos. 1/2 (2013).

11 See Paschalis M. Kitromilidis, "The Legacy of the French Revolution: Orthodoxy and Nationalism," in The Cambridge History of Christianity, vol. 5, Eastern Christianity, ed. Michael Angold (Cambridge: Cambridge University Press, 2006); Denis Vovchenko, "Creating Arab Nationalism? Russia and Greece in Ottoman Syria and Palestine (18401909)," Middle Eastern Studies 49, no. 6 (2013). 
The ruling body that elects the patriarch is the Holy Synod. Its members are the senior bishops of the patriarchate and members of the Brotherhood of the Holy Sepulchre. The patriarch himself is the head of the brotherhood and president of the Holy Synod, while the executive authority of patriarchal and synodical decisions has been entrusted since the late sixteenth century to four bishops in charge of different services: the dragoumanos (dragoman) is responsible for the relations with the state and the representatives of the other religions; the kamarasis deals with the internal affairs of the patriarchate; the skevofylax deals with property issues along with the supervision of the Status $q u o$ and the rights of the patriarchate on the holy sites, and the archigrammateas (secretary-general) deals with all secretarial affairs (correspondence, library and archives). In the mid-nineteenth century some other intermediary positions were created, such as the economic and real estate commissioners who are, respectively, the heads of the economic and real estate commissions and the ecclesiastical court supervisor.

\section{The Patriarchal Archives: A Recent Service of an Old Institution}

Despite its long administrative tradition, the Greek Orthodox patriarchate created a distinct archival service only in the early twentieth century and placed it under the authority of the archigrammateas. ${ }^{12}$ Today, most of the material is hosted in a two-story building within the patriarchal complex and contains documents from the tenth to the late twentieth centuries. The pilgrimage series and the real estate series make up the initial nucleus of the records. The former contains mainly caliphal decrees and sultanic firmans referring to the privileges and rights of the patriarchate over the sacred shrines, which were classified twice or three times through the centuries, according to the marks on their back pages. These documents ended up in seven separate subseries with specific numbering and are now part of the VII.B series of the archives' current inventory. The second series consists of property titles of monasteries, churches, rural areas and buildings, and is classified in the series from IV.A. to IV. $\Gamma$ in the current inventory. It is evident why these two series

12 Most information regarding the patriarchal archives comes from the introduction to Agamemnon Tselikas' inventory: Agamemnon Tselikas, Katagrafi tou archeiou tou Patriarcheiou Ierosolymon [Register of the Jerusalem patriarchate archives] (Athens: Deltio tou Istorikou kai Paleografikou Archeiou tou Morfotikou Idrymatos tis Ethnikis Trapezas tis Ellados, 1992), 17-32. 
were the most sensitive and valuable documents, and one can understand why the patriarchate was urged to establish an archival service to protect them.

When the archives were created in the early twentieth century, these two series were placed in the first chamber of the first floor. Responsible for this work was Dimitrios Ninos, a member of the local Greek Orthodox community who was fluent both in Arabic and Ottoman, assisted by a monk named Gorgias. In 1928, another monk named Andreas became the official registrar of the patriarchate and he mainly dealt with the establishment of the Great Estate Cadaster and with improving the organization of the two aforementioned series. At the same time, the patriarchate requested from its representative in Istanbul, Vladimiros Mirmiroglou, a person with a deep knowledge of the Ottoman language, the creation of an inventory containing the sultan's orders, which were kept in the archive of the Hexarchy of the Holy Sepulchre in Istanbul and were at that time transferred to Jerusalem. In a report that Monk Andreas wrote in 1945, he informed the Holy Synod that he had created an index (kleida) of the real estate series and finally suggested the creation of a historical archive, the realization of which proved to be difficult at the time due to the lack of translators for the Arab and Turkish documents.

The content of the archives was continually expanded through the post-World War II period. Initially, the incoming and outgoing patriarchal correspondence, kept in bound volumes along with a series of files of the administrative archive, were added and placed in two rooms of the upper story. A third chamber of the first floor was filled with files, cases, and registers from the economic and the real estate commissions. The existence of the Real Estate and the Pilgrimage series was gradually undermined because documents utilized in judicial cases were rarely returned to their original place. Archimandrite Kallistos, a former librarian of the patriarchate, tried in the early 1980 os to reorganize these two basic series, without success. Later on, in 1983, the Center for Byzantine Studies of the Greek National Foundation for Research (EIE) organized a mission, headed by Chrysa Maltezou and Kritonas Chrysochoidis, to accommodate the economic series archives, but the task was not accomplished.

In response to these failures, the Historical and Paleographic Archive (IPA) of the National Bank of Greece Cultural Foundation intervened. The IPA was established in 1974 to create a microfilm (and later a digitized) database of Greek-language manuscripts and historical archives that are kept in major libraries and archives in Greece and elsewhere. It also aims to provide consultation and information about the study of Greek manuscripts in collaboration with archivists, philologists, and historians. Since the foundation of the IPA, more than 200 missions have been completed, during which almost 9,500 
manuscripts have been digitized, as well as 20 full archival fonds (including the archives of the Catholic bishops of the Cycladic islands, the Greek Orthodox patriarchates of Alexandria and Jerusalem, the archdiocese of Cyprus, several monasteries of Mount Athos and Chalki Theological School), 150 codices and dozens of books from the eighteenth and nineteenth centuries. In parallel to the above missions, the IPA maintains a specialized library. It is currently completing an index of seventeenth- and eighteenth-century Greek codices, and has organized weekly seminars on paleography since the 1990s. These seminars, well-known among Greek academic circles, have been widely attended by philologists, historians, and other students, and have trained generations of paleographers in Greece. The IPA publishes a monthly bulletin presenting news about their collection of digitized documents and archives.

\section{The Agamemnon Tselikas Missions and Inventory, 1988-92}

The director of the IPA, Agamemnon Tselikas, and his team, whether working alone or collectively, carried out nine missions over the course of 170 days from July 1988 to November 1991. The objective of these missions was to create an inventory of the patriarchal archives. This was an ambitious and demanding project, full of methodological and linguistic challenges that nonetheless resulted in an inventory published in Greek in $1992 .{ }^{13}$ One might imagine that the classification of the patriarchate archival material would come after the list of services and offices of the institution. However, the distribution of power and duties among commissions within the patriarchate was often fluid and at times very much centralized around the patriarch. Therefore, the classification according to bureaucratic procedure was not always respected and this is reflected to a large degree in the organization of the documents. Tselikas' team tried to maintain the original classification of the material and add new categories whenever possible. Even though inconsistencies in the previous classifications were occasionally detected, these were left untouched in order to preserve the history of the archive itself. At times, there are gaps between registers or files, which are due either to the loss of material or to the fact that even when this work was underway, the patriarchal services had not yet organized the material. The team also tried to keep the original writing on the boxes, even though words were sometimes spelled incorrectly. This preserves an idea of what the bureaucratic mindset could have been at different times. The matching of labels with content was always checked and, whenever there was an

13 Tselikas, Katagrafi tou archeiou [Registry of the archives]. 
inconsistency, this was mentioned. Many documents are dated according to the Muslim calendar and a few older documents according to the Byzantine calendar. Dates of both systems were maintained but the archivists also provided the date in the current Gregorian calendar. The two basic criteria for classification were the content and the form of the material. Concerning the content, Tselikas structured the material around five major themes: economy, real estate, pilgrimage, administration, and correspondence. As for the form, two different kinds of records were distinguished: the registers and the codices on the one hand, and the nonbound (or flyleaf) documents on the other. Thus, he created nine separate series and numerous subseries, which are indicated with codes combining Latin and Greek numerals.

The financial series (registers and codices) consists of twelve subseries whose codes range from I.A to I.IB. The first (I.A) contains 392 registers of an elongated shape, classified during the 1983 mission of the EIE. The majority dates from the mid-seventeenth to the mid-nineteenth centuries. They are mostly economic and income registers, diaries and volumes regarding the patriarchate's budget, expenses, and different sources of income. The following seven subseries (I.B to I.H) created during the IPA missions contain registers of income and accounting books of the patriarchate's different services and especially of the economic commission and the Holy Sepulchre from the

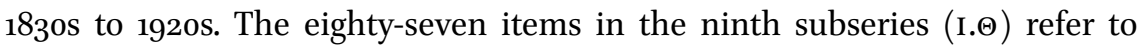
the auxiliary services of the patriarchate's branches and several monasteries in Palestine, while the items starting in 1843 and ending in 1898 of the tenth (I.I) subseries refer to institutions outside Palestine. The eleventh series (I.IA) contains 243 boxes of receipts of the economic commission starting in 1882 and ending in 1909. Finally, the twelfth series (I.IB.), "Duplicates of Food Management," consists of small duplicated sheets from 1890 to 1910, with the following inscriptions: "Usage of olive oil, soap, pulses, coffee, sugar, cod, octopus, potatoes, petrol and cheese, along with meat for the hospital, meat for the patriarchate, bread for the oil press of the Holy Cross and the harvesting of grapes."

The economic series of nonbound (or flyleaf) documents consists of five different series (codes II.A to II.E) deriving from the economic and real estate commissions, for documents of a purely an economic nature (rent collection, tax payments, loan bonds, etc.). Here, one can also find bonds and debt securities along with various documents of economic nature. These records are not only useful for the study of the internal structure of the patriarchate, but they also provide important information about the Greek Orthodox community, especially when it comes to the management of schools, hospitals, and other 
philanthropic initiatives of the patriarchate. Moreover, catalogs of suppliers to the patriarchate and remuneration statements of Arab and Greek technicians and workers of the patriarchate offer insights into the relations of the institution with the two subcommunities.

The registers of the real estate series contain three different series (codes III.A to III.Г) covering a long period from the eleventh to the early twentieth centuries. The first one (III.A) encompasses registers of dowries (inventories of movable objects of different temples and monasteries or services), along with lease and land registers in Greek and other real estate commission documents. Some real estate commission registers have economic content but are not integrated into one of the two economic series because they refer to specific edifices. Similarly, the correspondence of this commission was not placed in the correspondence series, but rather remained here. The second subseries (III.B) is part of the present-day documentation of the patriarchate and therefore remains at the secretary-general's office. A third subseries (III. ) includes nineteen land registers in Arabic and Ottoman and those that appear in the inventory as undeclared (adilon).

The nonbound (or flyleaf) documents of the real estate series contain five subseries (IV.A to IV.E). The first, which had been partly classified and registered by Dimitrios Ninos and the monk Andreas, comprises 239 tubes with a special external inscription. In their interior, one may find wrapped documents, perhaps the most valuable material of the patriarchal archives. Most of the documents are in Arabic and Ottoman and are rich in insights about diplomacy and the topography of Palestine; Jerusalem in particular. One of the oldest original documents of the archive is dated to 1166, during the Crusades. The text is in Arabic but the signature is in Greek (IV.A.218, 1). The initial numbering of the cylinders remained unmodified and the documents inside were classified in chronological order, with undated documents placed at the end. In some cylinders, the external inscription does not match the content of the documents or their actual number. This is due to problems with the earlier classification systems that were inherited by subsequent efforts. Tselikas' team preferred to leave this unchanged but noted the problem. The monk Kallistos must have arranged the second subseries of the real estate flyleaf documents (IV.B) according to city or region. These documents have been placed in green envelopes and they are dated up to the 1940s. The third subseries (IV.Г) contains property titles of the Old City of Jerusalem mostly in Arabic and Ottoman, and is sorted by neighborhood. The fourth subseries (IV.s) consists of files concerning various real estate cases with no apparent link to the patriarchate's housing service. This subseries also contains bundles of documents from 


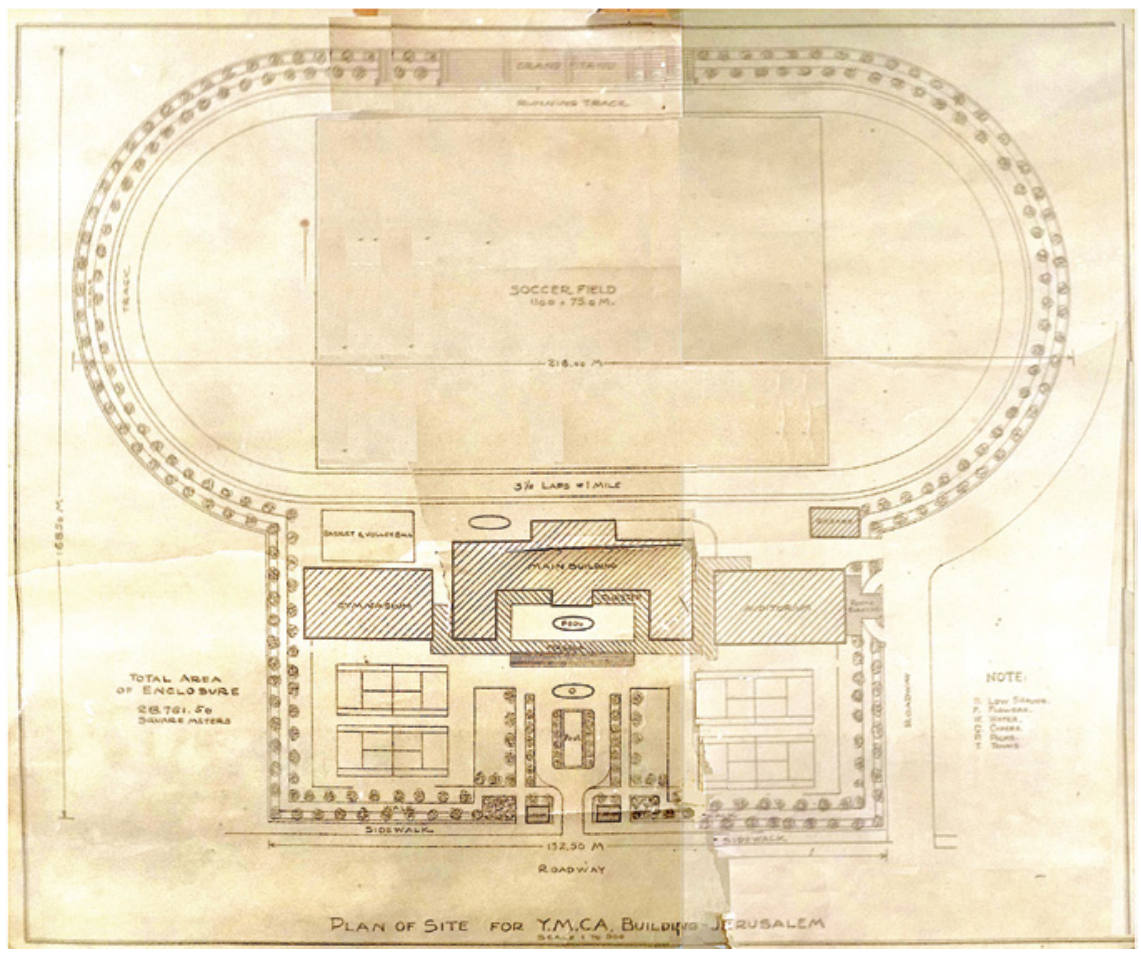

FIGURE 6.1 Plan of site for YMCA building and soccer field in Jerusalem. AEPI, IV.E, 14, JERUSALEM: YMCA BUILDING (SOCCER FIELD).

previous temporary classifications and other scattered documents. Three different files (112-14) have been added to this series, along with property titles and other official documents from the brotherhood's real estate in Bessarabia. The fifth series (IV.E) consists of architectural and urban plans of Jerusalem (fig. 6.1) and other towns and regions under the patriarchate's jurisdiction.

The pilgrimage series contains registers dealing with pilgrims (codes V.A to V.s). The material consists of donations, arrangements for the accommodation of pilgrims in monasteries and residencies, and the pilgrim's identifying information (name and birthplace) beginning in the early nineteenth century. It is a valuable source that could be used to map the profiles of Orthodox visitors to the sacred shrines. The administrative series includes codices in six separate subseries (VI.A to VI. $\mathrm{T}$ ). The first (VI.A) contains 171 official patriarchate letters glued on linen and stapled to one another. The

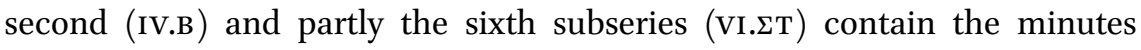
of the assembly of the Holy Synod and different sets of memoranda and 
regulations, which are still in use by the secretariat-general. The third series (IV.r) deals with the internal administration of the patriarchate, while the fourth (VI. $\Delta$ ) contains codices with information about fundraising from the Greek Orthodox laity and the clergy. The fifth part (IV.E) contains the previous inventories of the archives and the library.

The nonbound (or flyleaf) documents of the administrative series (codes VII.A to VII.E) contain some of the most valuable material of the archive and are classified in seven different subseries. The first (VII.A) contains scattered letters from several patriarchs from the mid-seventeenth to the midnineteenth centuries regarding fundraising and other issues. The subseries VII.B consists of the former pilgrimage series, whose previous classification was maintained. The 1,16o items divided in seven different sections are important from both an aesthetic and historical point of view. They include sultanic orders of the Mamluk sultans of Egypt, many of which are three to five meters long, as well as orders of the Ottoman sultans with golden and colorful monograms. They concern several matters and are dated from the thirteenth to the mid-nineteenth centuries. The third subseries (VII.厂) contains Arabic and Ottoman Turkish documents, mainly of a legal nature, and property titles of pilgrimage sites, administrative and other various cases, and is dated for the most part from the seventeenth to the late eighteenth centuries. They are particularly indicative of the variety of court cases the patriarchate was involved in during its long life. In the fourth subseries (VII. $\Delta$ ) there are administrative records concerning many different matters from the first half of the twentieth century. The external indications along with the internal classification of the letters in this subseries (the first forty-two are in metal) reveal the great change that occurred in the patriarchate's bureaucratic system in 1900 with the classification of the documents according to subject. The fifth subseries (VII.E) was created by administrative documents, but is classified by case. Among the thirty-one different cases, one finds the "Antioch affair" of 1906, the "Affair of Melbourne and Sydney" of 1901-3, and the "Cyprus affair" of $1902-7$.

The correspondence series (codices and nonbound documents from VIII.A to VIII.H) consists of eight different subseries of which only the third and the eighth contain nonbound documents while the rest consist of codices. The first series contains 311 volumes of incoming correspondence classified according to the sender's location and dating from the 1830 s to 1900. An archivist not only produces archives, but organizes and handles archives from other authors, and that is indeed what we see here. With the exception of codes VIII.B.1a and VII.B.1, the second series (VIII.B) is made up of 76 codices containing copies of outgoing letters that have retained the original numbers and 
date from 1843 to 1951 . The VIII. $\Gamma$ subseries is directly related to the series VII.s of the administrative series. The subseries VIII. $\Delta$ is the equivalent to VIII.B but containing telegram copies from 1883 to 1903 . The series VIII.E and VIII.Z contain the auxiliary books for the classification and retrieval of documents and letters in the series VII.s, VIII.B and VIII.r. Finally, the subseries VIII.H containing drafts of outgoing letters is directly related to the VIII.A subseries of these records and viII.B, where we find the final version of the very same letters.

Last but not least, the ninth series, consisting of the special correspon-

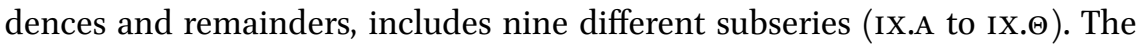
first six contain codices with copies of incoming and outgoing letters that were not integrated into the previous Correspondence series either because they did not belong to the general administration of the patriarchate or because the people who wrote them were on a special mission. One may find here the correspondence with the Russian consulate in Jerusalem along with the church branch of the Holy Sepulchre in Izmir or in Moscow. The seventh subseries contains files with letters and documents of the personal affairs of members of the Brotherhood (patriarchs included), as they were discovered in their remaining belongings after they died. In the eighth subseries (IX.H) the Tselikas team integrated in chronological order various letters in Greek, French, Russian and Arabic. This material was dispersed among several registers and files and had remained unclassified within the correspondence series.

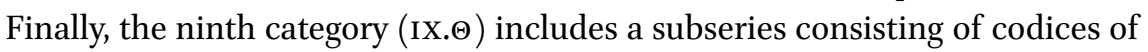
several bound original letters, copies and telegrams in Arabic.

Most of the above-mentioned material dates from the eleventh/twelfth to the mid-twentieth centuries. In the twenty-five years since the publication of the Tselikas inventory, a considerable number of twentieth-century documents has been added to the archives of the patriarchate. This material concerns the secretary-general during the interwar period and especially the years after World War II. The documents deal with the relations of the patriarchate with other churches in Jerusalem, interfaith events in which the patriarchate participated and the relations of the patriarchate with the Mandate authorities. ${ }^{14}$ It also contains school records of the postwar period, material concerning the

14 Konstantinos Papastathis and Ruth Kark, “The 'Politicization' of the 'Religious': The British Administration and the Question of the New Regulations of the Orthodox Patriarchate of Jerusalem, 1938-1941," Middle Eastern Studies 50, no. 4 (2014); Konstantinos Papastathis, "Religious Politics in Mandate Palestine: The Christian Orthodox Community Controversy in the Thirties," British Journal of Middle Eastern Studies 43, no. 3 (2016). 
Greek Orthodox presence in other Jordanian and Palestinian cities, economic records and other materials. This material has yet to be fully inventoried.

\section{Using the Patriarchal Archives: From Fraternal and Regional to Urban}

In the previous century, orientalists, often of Catholic or Protestant origins, studied the Christian communities of the Middle East through an essentialist, culturist approach, often without any consideration of internal or external dynamics. ${ }^{15}$ However, two parallel movements were in progress in the first decade of this century. The narrative presenting Christians as victims of the Muslims was accentuated in publications of public history, which tended to be emotionally intense, critical of Muslims, and lacking in historical rigor. ${ }^{16}$ In contrast, a more scientific approach dealt with the communities through anthropology and historical anthropology in order to analyze the dynamic relationship of the communities within their political and socioeconomic context, taking into account factors such as the state, territory and gender. ${ }^{17}$ For historians to be able to focus on the history of these populations and their interaction with other local religious communities, many obstacles remain. The often-fragile position of the Christian communities in an unstable political and geopolitical context, along with their almost existential

15 Otto Meinardus, Coptic Saints and Pilgrimages (Cairo: American University in Cairo Press, 2002); Meinardus, Monks and Monasteries of the Egyptian Deserts (Cairo: American University in Cairo Press, 1961); Georg Graf, Geschichte der christlichen arabischen Literatur, 5 vols. (Vatican City: Biblioteca Apostolica Vaticana, 1959); Pierre Rondot, Les Chrétiens d'Orient (Paris: Peyronnet, 1955); Jean-Pierre Valognes, Vie et mort des chrétiens d'Orient: Des origines à nos jours (Paris: Fayard, 1994). We owe many thanks to Stéphane Ancel for clarifying the historical discussion on the matter and for providing titles for the notes 15,16 and 17 .

16 Annie Laurent, Les chrétiens d'Orient vont-ils disparaitre? Entre souffrances et espérance (Paris: Salvator, 2008); Sébastien De Courtois, Le nouveau défi des chrétiens d'Orient d'Istanbul à Bagdad (Paris: Lattès, 2009);Jean-Michel Cadiot, Les chrétiens d'Orient:vitalité, souffrances, avenir (Paris: Salvator, 2010).

17 Bernard Heyberger, "Pratiques religieuses et lieux de culte partagés entre islam et christianisme (autour de la méditerranée)," Archives de sciences sociales des religions, no. 149 (2010); Sossie Andézian, "Formation des identités palestiniennes chrétiennes. Églises, espace et nation," Archives de sciences sociales des religions, no. 149 (2010); Anna Poujeau, "Renouveau monastique et historiographie chrétienne en Syrie," Archives de sciences sociales des religions, no. 151 (2010); Bas ter Haar Romeny, ed., Religious Origins of Nations? The Christian Communities of the Middle East (Leiden: Brill, 2009). 
suspicion of each other, prevents them from sharing their archival material, which is often extremely rich and quite often unexamined. This has been a problem for some Jerusalem communities and also for the Greek Orthodox community, both Arabs and Greeks. The Open Jerusalem project seeks to address this kind of problem through the opening and interconnection of different archives and sources.

Nevertheless, a fundamental question arises: are all archives appropriate for the study of citadinité? In other words, how can the Brotherhood, the community or ecclesiastical archives be useful for the study of urban citizenship? To answer such questions, we need to take into account the fact that citadinité does not exist per se. The concept is to a large degree determined by its explicit or implicit application to a limited scale (communal or at the level of the brotherhood) or to a wider one (regional or global). Both the brotherhood and the regional aspect are particularly evident in the patriarchate, an institution that is simultaneously spiritual and business-oriented. The producer and the author of the bulk of its archives remains the brotherhood. More restrained than the Greek Orthodox community, the brotherhood only concerns the senior clergy, which is predominantly Greek. The jurisdiction of the patriarchate stretches beyond the city of Jerusalem, and its head, namely the head of the brotherhood, is called "the Patriarch of the Holy City of Jerusalem and all Palestine, Syria, Arabia, beyond the Jordan River, Cana of Galilee, and Holy Zion." The question, then, is to what extent the archival material allows us to transcend the contrasting scales of the brotherhood, whose functioning has been described as that of a "closed corporation," and the regional scale of the patriarchate's jurisdiction. Does the material oscillate between the two extreme scales of analysis and finally rest on the city or does the city exist as a normative category to explore urban citizenship? A more systematic study of the Tselikas inventory and of the material may provide some preliminary answers to these questions. ${ }^{18}$ Let us examine some of the potential paradigms.

In material terms, the patriarchate identifies itself with the city of Jerusalem through its numerous properties. However, describing real estate and edifices does not suffice in addressing urban citizenship. Common urban identity is developed when people reside, live, and interact within the city. We are able to trace these aspects of citadinité through petitions, for instance. The bulk of the petitions in the archive lies in the seventh subseries of the administrative series nonbound documents (VII.Z.1-5). They are written in Greek and Arabic and cover the period from 1884 to 1911 . The first registered petitions

18 The translation of the inventory for the period $1840-1940$ is available on the website of the Open Jerusalem project (www.openjerusalem.org). 
must have started when the number of foreign language petitions addressed to the central Ottoman administration started to diminish, as Avcl, Lemire, and Özdemir show in this volume. A possible explanation is that after the Tanzimat and the consecutive set of regulations for the millets, the Greek Orthodox petitioners preferred to address their demands to their own religious institution, which was also much closer to them than Istanbul. During the aforementioned period, the patriarchate received thousands of petitions from the area of its jurisdiction, but not all of them were signed in the same way. In the petitions sent from Jerusalem, the author often added under his or her signature the term "Jerusalemite" (fig. 6.2) or "resident of Jerusalem." Most likely, the addition of this sign of urban identity stems from the hope that the patriarchate would better treat their demand. Indeed, the request of a person living in or originating from Jerusalem probably had priority over others because the patriarchate had the possibility of immediate social control over the petitioner. Petitions on subjects such as charity, dispute mediation, or even the patriarchate's intervention in releasing someone from prison could be more efficient given the positive recommendations from individuals of the same social milieu or at least in the absence of negative rumors.

Among the charitable services that the patriarchate provided to the members of the Orthodox congregation, accommodation for destitute people must have been one of the most popular. Several housing service files refer to this

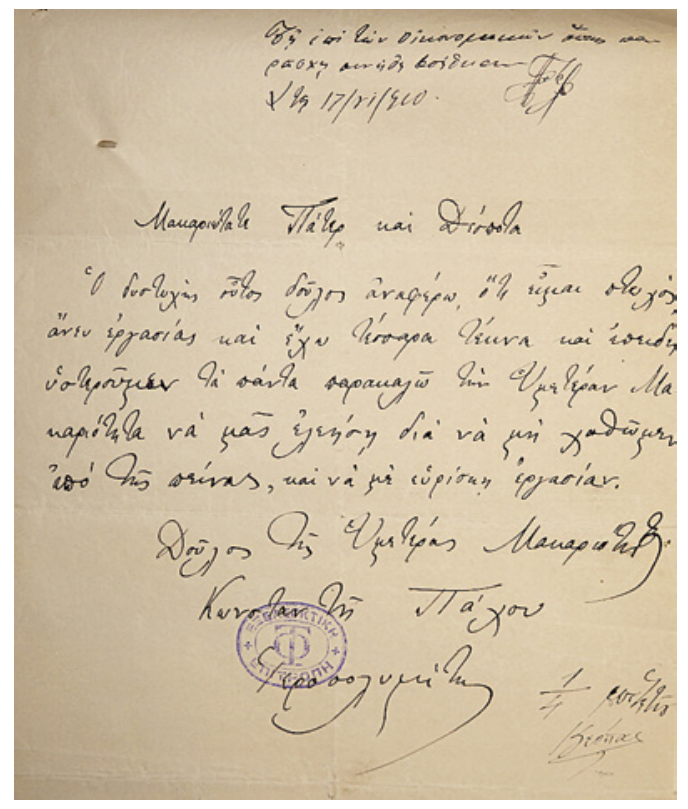

FIGURE 6.2

Petition, received on June 17, 1910, with the mention of "Jerusalemite" after the petitioner's signature. AEPI, VII. Z. 3, PETITION OF KONSTANTIS PACHOS TO THE GREEK ORTHODOX PATRIARCH. 
matter: rent payments registers are found in the real estate series (III.A.63); a memorandum on housing issues is found in the collection of real estate nonbound documents (IV.A.6o); and a document on house repairs is found in the

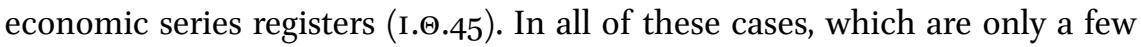
of many, the files indicate as beneficiaries "our indigenous" people (imeteroi ithageneis) that is, the Palestinian Arabs. Thus, the patriarchate distinguished the Palestinians from the Greeks (who were mentioned as such) and from Muslims (who apparently were not considered as "theirs"). It is also worth noting here that the houses let by the monastic Brotherhood of the Holy Sepulchre at very low prices were often within the Greek Orthodox monasteries of the Old City. Thus, the place of worship and the place of residence coincided.

The baptismal and wedding registers of the patriarchate may at first seem irrelevant to the study of citadinité. However, other research work based on such material shows that Jerusalem's holy character and everyday life may coexist without necessarily coinciding. ${ }^{19}$ This material, which is not inventoried and belongs to the ecclesiastical court of the Greek Orthodox patriarchate and the Church of St. James contains baptismal registers covering most of the first half of the twentieth century and wedding registers from the 1920s. The majority of the registers are in Greek, except for the St. James' baptismal records, which are in Arabic. This previously unexplored material sheds new light on the Greek Orthodox community of the city during the transition period between the Ottoman Empire and the British Mandate eras. The authors used the registers to investigate "communal affiliations, transitions of identity, the impact of modernity as well as notions of sacred space." They studied relations between Palestinian Arabs and Greeks, and between these communities and the city. Their work has shown that the feeling of belonging to the city of Jerusalem is not necessarily linked to any kind of perpetual or everyday "holiness." On the contrary, the authors argue that "the proximity to the holy sites bears little impact on private Christian life." Despite the ability to hold rituals in the holiest sites of Christianity, baptisms were commonly held at home or in parish churches (over twenty sites in the Old City alone). The way residents appropriated Jerusalem's holiness is a factor of citadinité is in stark contrast with the way institutions envisage the Holy City. Additional material from the ecclesiastical court, which comprises minutes of the courts and wills (or testaments), written sometimes both in Arabic and in Greek (fig. 6.3), permits further investigation of the above matters.

19 Merav Mack, Angelos Dalachanis and Vincent Lemire, "Matrimony and Baptism: Changing Landscapes in Greek (Rum) Orthodox Jerusalem (1900-1940)," British Journal of Middle Eastern Studies, published January 30, 2017, doi: 10.1080/13530194.2016.1273093. 


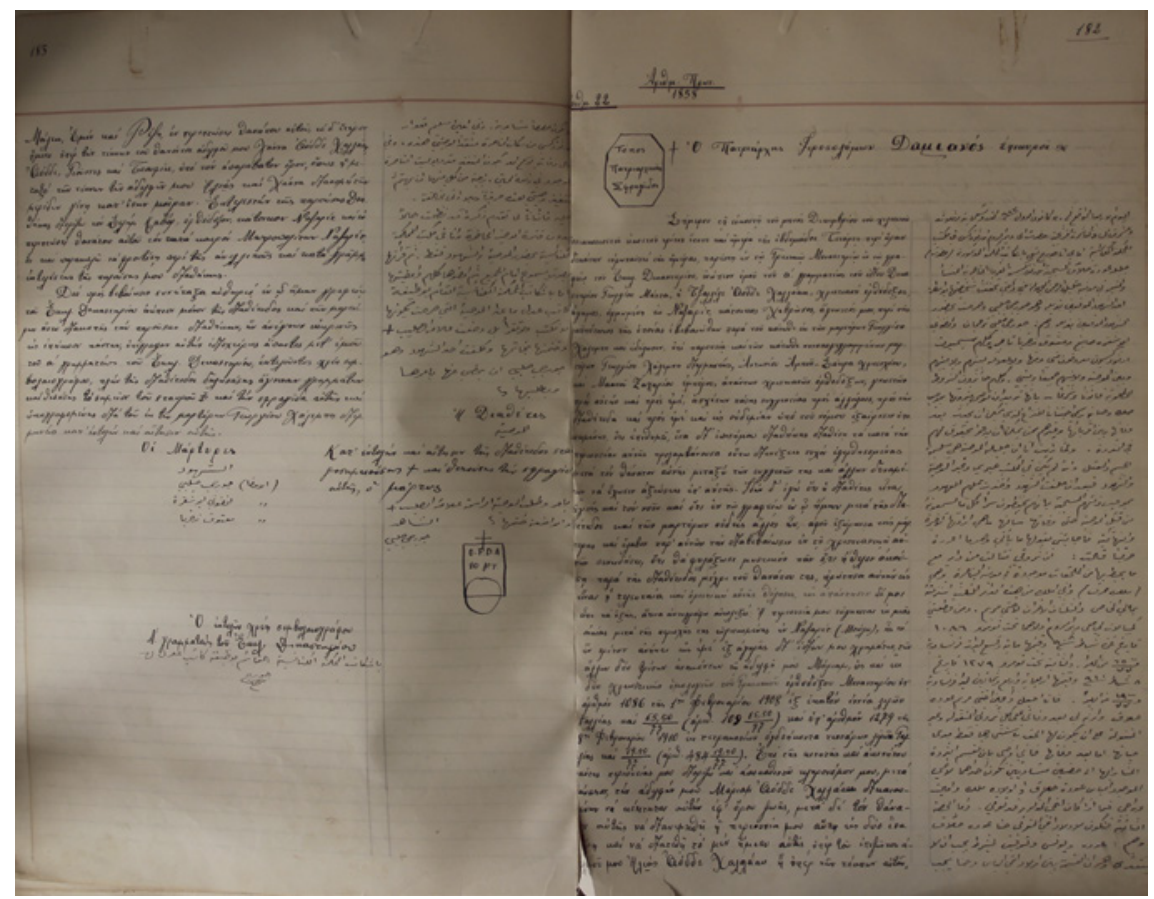

FIGURE 6.3 Testament dated December 20, 1923, in Arabic and Greek.

AEPI, ECCLESIASTICAL COURT, CODICES OF TESTAMENTS, 1858/22, 182-83.

\section{Concluding Thoughts}

Archives are one of the principal instruments in the construction of an institution or a community's identity. ${ }^{20}$ An archive's documents reflect the interactions between the communities and identities themselves, and there is an enormous concentration of such interactions in Jerusalem. That the archive inventory has now been presented in a language other than Greek for the first time is, we hope, a first sign that the Open Jerusalem project has already begun to contribute to the work of archivists in Jerusalem. That said, a number of issues remain. More so than the secrecy of documents or difficulty of access, the main problems arise from the enormous mass of the material. One of the particularities of the patriarchal material is that it involves untapped archives of a quantitative nature, which require extensive treatment. It is a time-consuming process, especially when it comes to registers. In these cases, handling the material necessitates the establishment and development of databases. The language issue often creates additional difficulties. 
For instance, the names of people of the two subcommunities (Arab and Greek) are often given in the two respective languages. Discrepancies in the transcription of names from one language to another often make it difficult to match them. This is an old challenge, for the language problem surfaces in various Jerusalem archives due to the continuous transliterations of names and places when traversing language and community frontiers. How, then, can such material be organized and prepared for future research? Practical difficulties may hinder the creation of a historical archive, but the Open Jerusalem database will mobilize all possible means to open the patriarchal archives and put them in dialogue with other Jerusalem records. Improving the accessibility of the patriarchal archives may be a great gift to academia, and to humanity on the whole. 